This accepted manuscript is published in the Int. J. Knowledge-Based Development.

Fellnhofer K. (2017): Evidence revisited: Literature on smart specialisation calls for more mixed

research designs, International Journal of Knowledge-Based Development, 8(3), 229-248.

Evidence revisited: Literature on smart specialisation calls for more mixed research designs

Katharina Fellnhofer

Research and Innovation Management $\mathrm{GmbH}$

Marktplatz 7A, 3371 Neumarkt an der Ybbs, Austria

Email: info@research-and-innovation-management.com

Lappeenranta University of Technology

School of Business and Management

P.O. Box 20, FI-53851 Lappeenranta, Finland

Email: katharina.fellnhofer@lut.fi

\title{
Bibliographical notes:
}

As owner of a small and medium sized company in Austria Katharina Fellnhofer is engaged in a European Union's Horizon 2020 project entitled ONLINE-S3. Additionally, as Erwin Schrödinger Fellow she works in the field of Entrepreneurship Education as a Research Visitor at the Lappeenranta University of Technology. She holds a Ph.D. in economic sciences from the University of Innsbruck, Austria.

\section{Acknowledgement}

This project has received funding from the European Union's Horizon 2020 Research and Innovation Programme under grant agreement No. 710659, ONLINE-S3. This article reflects only the author's view. Neither the Research Executive Agency nor the European Commission is responsible for any use that may be made of the information it contains.

The author would like to express great appreciation to Olivia Wais for her assistance.

\begin{abstract}
The aim of this paper is to present an overview of the applied research methods that have been used to examine smart specialisation. For this review, papers from various sources were collected and reviewed multiple times. The findings show that only a few papers applied mixed research methods. Primarily, there are more qualitative than quantitative methods used among papers concerning smart specialisation. More efforts to use mixed methods in smart specialisation could yield findings that are applicable to knowledge-based policymaking. To further illuminate the research discipline of smart specialisation, applying advanced, quantitative research techniques would enrich future efforts of all quadruple helix stakeholders engaged in smart specialisation.
\end{abstract}

Keywords Smart specialisation, literature review, knowledge-based policy making, research and innovation strategies

\section{Introduction}

The goal of this paper is to present a literature review of published papers concerning smart specialisation. This work provides a thorough overview of these contributions and examines whether and how the studies employ an applied research design. Since smart specialisation strategies are becoming increasingly essential for national and regional authorities to improve their policy agenda (Foray et al., 2011), it is important to determine whether there is enough information on this topic. Moreover, it is essential to explore which academic papers use which methodologies for which purpose and yield which results. Overall, reviews are integral to 
This accepted manuscript is published in the Int. J. Knowledge-Based Development.

Fellnhofer K. (2017): Evidence revisited: Literature on smart specialisation calls for more mixed

research designs, International Journal of Knowledge-Based Development, 8(3), 229-248.

designing smart specialisation strategies, whereby case studies represent the type of methodology applied the most in the research discipline of smart specialisation.

This contribution considers the definition of "smart specialisation" as the notion of smart, sustainable and inclusive economic growth, which represents a central policy of the European Commission (EC) (EC, 2010). This review is guided by prior work such as those of Foray and colleagues (Foray et al., 2011, 2012; Foray, 2014, 2015), which involve creating research and innovation strategies for smart specialisation. While the papers classified under the "qualitative" research stream in this contribution tend to explore smart specialisation from a policy perspective (e.g. Lerro and Jacobone, 2014; Komninos, 2016), the papers framed as "quantitative" are contributions that, in their fundament, study regional diversification processes, cross combine statistics and provide insights for what can be defined as smart specialisation policy (e.g. Maeng and Nedovic-Budic, 2010; Grant and Chuang, 2012; Battaglia, 2014; Yigitcanlar, 2014; Gridneva and Noennig, 2014; Gadille and Siarheyeva, 2014; McMillan et al., 2016). This extensive approach to smart specialisation - from a regional to a European perspective - highlights the applied methods and illuminates neglected research designs.

Furthermore, this study draws attention to the "quadruple helix model", which categorises stakeholders into university, government, industry and society (Etzkowitz and Leydesdorff 1995; 2000; Shinn, 2002; Etzkowitz, 2003; Garrett-Jones et al., 2005; Fogelberg and Sandén, 2008; Howells et al., 2012; Presenza et al., 2014; Carayannis and Rakhmatullin, 2014). Using a multi-stakeholder approach, smart specialisation is relevant for knowledge-based development and innovation policy because entrepreneurial discovery is the heart of both interconnected processes (Martinus, 2012; Romano et al., 2014; Gadille and Siarheyeva, 2014; Secundo et al., 2015; Kim et al., 2016).

This review is structured as follows. First, this paper begins with a methodology section, which explains how the reports for this work were selected and reviewed. Next, the results of the literature review are described and divided into quantitative, qualitative and mixed methods. The review concludes with a discussion, which reports the core findings and limitations of the review and explains the implications of the results.

\section{Methodology}

The data was collected by applying recommended methodologies for conducting a literature review (Denney and Tewksbury, 2013). The papers were obtained using the search words "smart specialization" and "smart specialisation" for the abstract, title and keywords of studies in literature databases such as Scopus, EBSCO and ScienceDirect until the end of 2015. However, some documents recently published after 2015 are also discussed in this review. All collected papers were organised by reviewing them multiple times to eliminate duplicates and delete papers that did not concern the topic of smart specialisation. All papers were read to determine the aim, methodology and findings of each effort. Thus, after eliminating duplicates and papers not focused on smart specialisation, 131 papers were selected for discussion in this literature review.

\section{Results}

The results are categorised in qualitative and quantitative results. While qualitative methods are cases studies, interviews, literature reviews, classification, theoretical models or other similar conceptual frameworks (e.g., roadmaps, content analysis, evaluations, mappings, framework analysis etc.), quantitative methods are classified as exploratory studies, questionnaires, descriptive analysis, structural equation models, factor/cluster analysis, regression analysis, correlation analysis or similar methods (e.g., bibliometric analysis, Delphi methods, experts panels, cross-impact analysis, cross-sectional data set, etc.). 
This accepted manuscript is published in the Int. J. Knowledge-Based Development.

Fellnhofer K. (2017): Evidence revisited: Literature on smart specialisation calls for more mixed

research designs, International Journal of Knowledge-Based Development, 8(3), 229-248.

\subsection{Qualitative Methods}

Most of the works examined in this review were case studies. Within this context, cases often focus on overall regional development in terms of its smart specialisation strategies. For instance, the case study titled "Towards a New Era for Regional Development: Investing in Leadership" by Anselmo and Cascio (2011) shows that smarter policymaking is necessary to encourage economic and innovation development by giving small amounts of money to small and medium sized enterprises (SMEs). Another paper describes cases to form a model for knowledge exploitation considering international cooperation (Casaramona et al., 2015). Clar and Sautter (2014) discuss local research-driven cases using clusters of global knowledge flows. Kroll et al. (2016) explain that in German speaking countries, the implementation of regional innovation strategies developed from practical cases has led to improvements in methodologies, communication and coordination among stakeholders. Moreover, Rosiello et al. (2015) argue that regions should not attempt implementation of only one type of innovation system. Furthermore, Komninos et al. (2014) discuss ongoing research of innovation strategies (RIS) under crisis situations and explains the main challenges that have to be overcome, including the readiness and credibility of public authorities to create these strategies, companies' enthusiasm, the availability of funds, being innovative in a crisis and whether the drivers of specialisation garner competitiveness. Overall, the findings of Georghiou et al. (2014) demonstrate how a lack of critical mass can be mitigated by maximising skills and competences in small, peripheral economies for smart specialisation.

Another research stream in smart specialisation constitutes cases studies focused on different sectors or target groups. For example, Petraitè and Čeičytė (2014) conducted a case study concentrating on high-tech organisations in the medical sector and the decomposition of the responsible innovation process. Another paper discusses the problems of companies located in rural regions but demonstrates how a smart specialisation model ameliorates those issues (Olaniyi and Reidolf, 2015). Using a large technical community as an example, Perry et al. (2011) argue for revitalizing the exploration and production taxonomy and demonstrate how problems can be solved with this concept. Lerro and Jacobone (2014) discuss the National Energy Technology District, which has impacted business, geographical and institutional factors. Monsson (2014) explains that development agencies can create business support in the form of successful and alternative models that differ from smart specialisation models.

In addition to general case studies and case studies that focus on certain sectors, some studies in smart specialisation use case studies that focus on certain regions. For example, Kropelnytska and Vusyatytska (2015) claim that Ukraine's main issue with cluster policies based on innovative development is because of lack of financial support, which can be addressed at the local and state levels. Scutaru (2015) discusses the possible identification of clusters in Romania, the fields of activity that were executed over several years and how the clusters operate at this moment. Another paper examines Romania's economic resilience by observing and analysing the national economy and the growth associated with implementation of smart specialisation strategies (Zaman and Georgescu, 2015). Another case study highlights the position of Polish entrepreneurs, develops support initiatives describing the key elements of the programme in detail and defines the process of creating a comprehensive regional system (Golec and Lipińska, 2015). Rucinski et al. (2013) states that Polish smart specialisation should be used in e-Health technologies, specifically for advanced patient monitoring systems and data transmission. Finally, the article "Clusters and Smart Specializations" explains that implementation of smart specialisation using the cluster developing policy could be advantageous in terms of economic growth to multiple Polish regions (Perło, 2015).

In addition to reports using case studies, there are articles reflecting on smart specialisation. First, Coffano and Foray (2014) describe the essence of smart specialisation as a policy process. Additionally, they provide information on the policy framework. Pauna (2015) highlights the 
This accepted manuscript is published in the Int. J. Knowledge-Based Development.

Fellnhofer K. (2017): Evidence revisited: Literature on smart specialisation calls for more mixed research designs, International Journal of Knowledge-Based Development, 8(3), 229-248.

necessity to support economic growth and regional competitiveness by using cluster policies and smart specialisation strategies. Finally, the findings of Santini et al. (2016) suggest steps to reduce the thinkers and doers gap in the implementation of smart specialisation strategies.

Overall, there are many literature reviews concerning smart specialisation strategies across multiple regions. Gulc's (2015a) report explains methods to detect and identify smart specialisation in Polish regions by comparing methods, which can be beneficial when developing regions for future assessments of smart specialisation's influence. In "Fuzzy Clustering in the Evaluation of Intelligent Specialization of Polish Regions," Markowska and Jefmański (2012) evaluate the direction of smart specialisation in Poland. Sandu (2012) considers the theoretical and methodological elements of smart specialisation by examining its application in Romana using an evaluation of implementation opportunities and instruments described in the Innovation Union objectives. Reimeris (2016) provides an overview of the research and innovation system in Lithuania, which has not changed although smart specialisation strategies have been implemented. Jishnu et al.'s (2011) paper regarding pharmacy education in India provides information regarding how its outdated system can be changed by using an innovation ecosystem and quality management. In short, the development of smart specialisation strategies can be viewed as a continuous procedure.

Moreover, there are reviews that draw attention to missing gaps in the current debate regarding smart specialisation research. For instance, Camagni and Capello (2013) suggest a new taxonomy of European innovation patterns and also proposes innovation policies for each regional mode of innovation. Another work states that smart specialisation strategies are contributing to the transformation of regional economies (Dziembała, 2015). The report "Planning Local Economic Development in the Emerging World Order" explains that leadingedge regions and regional economic development practices must become smarter, more flexible, more experimental and more collaborative among stakeholders. Thus, well-developed scholarship is necessary to design organisations and practices (Feser, 2014). Hildreth and Bailey (2014) clarify place-based approaches, which underscore regions determining their own potential. The report also enlightens the concept of "missing space" and how this space can be filled; it also explains place-based, sub-national economic strategy. Iacobucci (2014) illustrates the theoretical and practical problems that arise while identifying links among technical areas within the same regions and among other regions. Additionally, the paper also provides suggestions regarding how to improve and implement smart specialisation strategies.

Other reviews regarding smart specialisation focus on technologies or specific economic situations. The paper "Smart Specialisation and Key Enabling Technologies in the New Regional Development Policy" illuminates what the concept consists of (knowledge transfer steps and cognitive steps) and also describes the output model, which includes the smart specialisation areas and key enabling technologies (Malik, 2014). Rusu (2013) argues that the concept of smart specialisation should be clarified for its operational implementation and use among policymakers in the wood processing industry. Markowska (2014) provides information regarding smart growth, smart growth components and economic resilience covering a specific region against an economic crisis.

Further authors provide helpful guidelines and models that support smart specialisation. For instance, McCann and Ortega-Argiles (2015) describe the concept of smart specialisation and the hurdles faced when using it. In this regard, the authors explain how smart specialisation can be integrated as a component of the reformed European Union (EU) cohesion policy. Another review shows how re-shaping the European regional policy can facilitate entrepreneurship for driving regional innovation (McCann and Ortega-Argilés, 2016b). McCann and Varga (2015) explain the features regarding the application of the smart specialisation model, the so-called RHOMOLO equilibrium model and the performance of the European Structural Funds. Another paper describes cluster policies that achieve economic growth (Mempel-Śnieżyk, 2013). In Morgan's (2016) report, the Basque model is described with its strengths and 
This accepted manuscript is published in the Int. J. Knowledge-Based Development.

Fellnhofer K. (2017): Evidence revisited: Literature on smart specialisation calls for more mixed

research designs, International Journal of Knowledge-Based Development, 8(3), 229-248.

weaknesses and the author discusses how the model is adapted to smart specialisation. Finally, the paper discusses four central problems, which are illuminated using the Basque experience, concerning regional innovation policy studies.

Other literature reviews describe the importance of smart specialisation itself. For instance, Romano et al. (2014) present innovation ecosystems as environments and discuss the problems that scientists and policymakers face regarding smart specialisation. The paper titled "Smart Specialization Strategies and Smart Cities: An Evidence-Based Assessment of European Union Policies" (Caragliu and Bo, 2015) attempts to fill the gaps between smart specialisation and smart cities by combining them into one framework, which resulted with the EU regions being on the smart specialisation path and the smart cities being more likely to emerge in smartly specialised regions. Further contributions on smart cities followed (e.g. Angelidou, 2015; Angelidou, 2016). Carayannis and Rakhmatullin (2014) review the conceptual and practical connections among theory, policy and practice in the context of smart specialisation strategies and discuss the "multi-focal lens" of the Quadruple and Quintuple Innovation Helixes view. The importance of Public-Private Partnerships, Public Procurement of Innovation and Smart Specialisation Strategies are presented in another review (Casado, 2014). Nevertheless, Dziedzic (2014) discusses the problems encountered while creating and using strategic documents relating to innovation. While a paper called "Innovating ICT innovation: Trentino as a Lab" provides information on the "Living Lab Public-Private-People-Partnership" (Ferrari et al., 2011), Filion (2010) summarises the present, compartmentalised context of the history of planning. Furthermore, Filion's report discusses the processes that planners need to implement in smart growth movements. In the review "Institutions, Smart Specialisation Dynamics and Policy", Grillitsch (2016) elaborates the influences on the context of the regional institutional framework configuration of smart specialisation dynamics and policy. Karo and Kattel (2015) describe the types of states, policies and administrative capacities, or routines, smart specialisation relies on. Moreover, the authors examine economies in the central and eastern European regions that have built rather different routines over the years. Kyriakou (2014) suggests that the tensions in the EU can be minimized by technology and research, which can also help support the EU in its trade, specialisation and production structures. Moreover, another review highlights findings on the early smart specialisation concept and its future (Landabaso, 2014). Furthermore, this paper explores the tools at smart specialisation's disposal and advances specific policy proposals and governance considerations. The paper by Dziedzic et al. (2014) highlights basic information on crowdsourcing and focuses on how crowdsourcing could be useful for smart specialisation in the EU. McCann and Ortega-Argilés (2014b) discovered that the policy architecture regarding smart specialisation's agenda will operate differently in each region because of governance issues and variations in the regional economic conditions. Later, McCann and Ortega-Argilés (2016a) illustrate the first experiences of smart specialisation's agendas, which include the types of policy periodisation choices made by the regions. The authors discuss the policy process so far and the challenges ahead.

In the field of smart specialisation, there are also many reviews that focus on different stakeholders. For instance, McCann and Ortega-Argilés (2014a) explain the regional entrepreneurship-promotion and innovation-promotion agenda, which is a main element of the EU Cohesion Policy's place-based reforms. One year before, McCann and Ortega-Argilés (2013a, 2013b) explored reforms made to the EU Cohesion Policy concerning its nature, rationale and logic. Later, Morgan (2015) answers questions on smart specialisation by providing success stories of its use. Additionally, the paper "Industrial Change and EU Programmes in Creating a Favourable Environment" focuses on defining the perception of the importance of EU programmes and the network and projects need for funding in the business environment. Moreover, a framework for improving the business environment is needed so that conditions allow companies to access funding for research and development, which will stimulate investment throughout the EU (Nastase et al., 2012). Another review by Brown 
This accepted manuscript is published in the Int. J. Knowledge-Based Development.

Fellnhofer K. (2017): Evidence revisited: Literature on smart specialisation calls for more mixed research designs, International Journal of Knowledge-Based Development, 8(3), 229-248.

(2011) discusses problems faced by biotechnology companies that want both faster and successful researching while lowering the cost of this process. In line with examining stakeholders from the business sector, a review produced by Wilson et al. (2015) defines the socio-economic effects of mineral and agricultural resource extraction on people in the targeted regions. The authors also propose policy options for ameliorating these negative effects. Another review by Santos and Caseiro (2015) clarifies the links among the entrepreneurial universities' concepts regarding the framework of smart specialisation.

Several reviews focus on specific regions. For instance, Peck and colleagues (2013) explain what has changed since 2010 in English regions because of the new United Kingdom Coalition Government. Another review describes the most important issues facing Podlaskie Voivodeship's implementation of eco-innovations (Korkosz-Gębska, 2015). Tomaszuk (2015) provides information on smart specialisation, including a theoretical definition, an explanation of how smart specialisation is implemented and an overview of the Podlasie region. The paper "Paradigm Change in Regional Policy: Towards Smart Specialisation? Lessons from Flanders (Belgium)" attempts to answer three questions: "What are the fundamental characteristics of the 'old' regional policies?", "Did the 'old' paradigm evolve into a new paradigm of regional policy?" and "And if yes, how did these changes materialize and what characteristics were affected?". Additionally, information is provided regarding how to implement changes associated with smart specialisation in Flemish regions (Vanthillo and Verhetsel, 2012). The results of the systematic literature by Gulc (2015b) describe the characteristics of the smart specialised regions in the EU, creation of smart specialisation strategy, strategies for financing smart specialisation and examples of how to recognise smart specialisation on regional levels. Dziemianowicz and Peszat (2014) highlight the process and effects of the development of smart specialisation in the Silesian and Warmian-Masurian Voivodeships, starting with development theories, a discussion and ending with doubts regarding the future situation of both regions. Furthermore, the book "Irish Economic Development: High-performing EU State or Serial Under-achiever?" by O'Leary (2015) provides information on future opportunities offered by the EU's smart specialisation policy and on future threats from international tax competitors. Also, the author expresses that if the Irish and the policymakers do not change business development, Ireland will become an under-performing EU state. The paper "Is Eco-innovation a Smart Specialization Strategy for Andalusia? One approach from the Multivariate Analysis" by Álvarez et al. (2014) researched the relationships among eco-innovation activities and their relative competitiveness.

Frameworks were also applied in several papers to provide information regarding smart specialisation. For instance, the paper by Boschma and Boschma (2014) draws attention to two policy concepts used to create a smart policy design that centres on economic renewal in the regions. To reduce the possible risk of policy disasters and policy capture, Foray (2014) discusses helpful principles for the policy process. The paper titled "Towards Leading Diverse, Smarter and More Adaptable Organizations that Learn" argues for considering organisations as learnable, emergent collectives that can learn together in an educational framework. Furthermore, Kowch (2012) discusses diversity in an organisational perspective and then describes the framework for smart specialisation itself. By analysing various projects, Ioana $e t$ al. (2015) discuss the involvement of communities in the process of academic research and innovation. In the article "Four Minutes to Four Years: The Advantage of Recombinant Over Specialized Innovation-RIS3 Versus 'Smartspec' ", Cooke (2016) used interviews to investigate the policy transition and the political framework's strengths and weaknesses. Also, the findings demonstrate the way in which three regions in Portugal received, comprehended and implemented smart specialisation strategies.

Several studies in smart specialisation use a content analysis method. Camagni et al. (2014) argue that regions that are similar to each other should be identified to prevent the use of inadequate strategies. Therefore, a territorial taxonomy is presented to create a regional 
This accepted manuscript is published in the Int. J. Knowledge-Based Development.

Fellnhofer K. (2017): Evidence revisited: Literature on smart specialisation calls for more mixed

research designs, International Journal of Knowledge-Based Development, 8(3), 229-248.

innovation strategy that suits the regional mode of innovation. The paper "Smart Specialization and Entrepreneurial Discovery: Theory and Reality" explains the concept of entrepreneurial discovery in terms of smart specialisation theoretically and practically, and then provides recommendations on this topic with more insights regarding the requirements for policies to identify and support initiatives and processes (Del Castillo Hermosa et al., 2015). Iacobucci and Guzzini (2016) explain that only a few regions considered themselves as relatable (identification of synergies among technological domains in the same region) and connected by technological domain (possible connection of the chosen domain with other regions) in terms of smart specialisation. The paper explains these divergences and offers guidelines to overcome these issues.

Baran and Hajduk (2013) applied a participatory and experience-based methodology by examining the solution of smart growth, thus determining that the implementation of smart specialisation strategies is a test for the communities. The authors Han et al. (2016) introduce a new, knowledge-based system that receives its knowledge by interaction with domain experts and continuously grows by adding rules, therefore minimising the costs of maintenance. In addition, the authors explain how information is processed and applied to the decision support process.

Capello and Kroll (2016) provide evaluations of smart specialisation strategies, specifically underscoring emerging bottlenecks and possible solutions to overcome them. The findings of a roadmap offer the different states, policies, and administrative capacities, or routines, smart specialisation presumes; however, it has been stated that central European regions have built alternative routines. Karo and Kattel (2015) provide general guidelines for the design and implementation of successful smart specialisation strategies. Nordberg (2015) explains the Mode 3 Knowledge Production System, Quadruple Helix Innovation and other related systems to discover possibilities to encourage regions into innovative development.

A paper by Naldi et al. (2015) mapped different ideas regarding smart specialisation. The findings in the paper describe the logic that lies behind policies regarding smart growth in rural regions. The paper also highlights smart development indicators and analysis and determines whether and to what these are of importance for the future. The findings of Bečić and Švarc (2015) illuminate the implementation of smart specialisation in the example of Croatia. It is concluded that smart specialisation is a useful strategy to replace horizontal and mutually disconnected policy measures. Gheorghiu et al. (2016) highlight a toolkit for foresight regarding smart specialisation and entrepreneurial discovery. Mapping was also used by Todeva (2015), who was attempting to unpack the topic of health technology clusters in England using the finding that under the framework of limited government intervention, markets strategies can encourage cluster growth and development.

\subsection{Quantitative Methods}

The paper titled "Selected Factors of the Regional Capital Determining Investment Decisions of the Companies form the Textile and Clothing Sector from Łódź Voivodeship" by Fabińska (2013) presents the survey results of priority factors of the regional capital from companies in the textile and clothing industry. Kroll (2015) provides results related to the ability of the smart specialisation process to change routines and practice governance. With quantitative data Muscio et al. (2015) discovered a different influence between Eastern and Western European regions of European in terms of funding regional economic growth. They concluded that smart specialisation can help in this matter by boosting governance of regional innovation systems' quality. Simonen et al. (2015) discuss the connections between regional industrial structure and economic growth.

Using empirical testing empirically, a paper by Benner (2014) asserts the need for smart experimentation. The applied tool is an addition to smart specialisation and is developed for evolutionary economics and relational economic geography. Borsi and Mikita (2013) explain 
This accepted manuscript is published in the Int. J. Knowledge-Based Development.

Fellnhofer K. (2017): Evidence revisited: Literature on smart specialisation calls for more mixed research designs, International Journal of Knowledge-Based Development, 8(3), 229-248.

the relationship between the support at the European-level for Framework Programmes and research and development statistics. Moreover, there are some regions that are entirely different regarding the structural composition of their framework and research and development programmes.

The paper titled "Industrial Complexes in Mexico: Implications for Regional Industrial Policy Based on Related Variety and Smart Specialization" by Gonzalez et al. (2016) highlights distinct complexities of implementing smart specialisation strategies in Mexico. Koszarek (2014) provides information on cluster fostering in Poland, stating that the recommendations are consistent with the smart specialisation model from the EC. One work explains the connection between smart specialisation strategies and social cohesion by examining the intensity and direction of relationships among regions (Bal-Domańska, 2013b). Another evaluates the relationships among regions implementing smart growth by assessing the intensity and direction of the relationships. In addition, the author Bal-Domańska (2013a) claims that the smart growth pillars' impact on economic cohesion suggest that the main factor of smart specialisation is represented by human capital creative resources. Another paper produced by Tsan et al. (2012) inspects the connection between industrial specialisation and economic contribution in the smartphone element industry.

Knašas (2014) reviewed the EU and the Lithuanian documents on research and development by exploring the published applications of smart specialisation, thus defining major research and development directions. One paper used empirical testing to demonstrate a pan-European test for improving the specialisation-diversity debate (van Oort et al., 2015). CIobotaru (2014) used conceptual tools to analyse the application of the public land use policy and state development planning.

The bibliometric method was used by McMillan et al. (2016), who state that Malta does not play a large role in smart specialisation. Nevertheless, the authors discovered that the currently researched locations in Malta show strengths in aquaculture. Also, findings of the Z. Hellwig's standard method applied by Miłek and Kapusta (2015) stress that the province Świętokrzyskie is hardly competitive in terms of economic growth. It would be advantageous for the region if the gap between this province and other regions was reduced. McCann (2015) explains the main regional and urban European economy features and illustrates the current re-design of the EU Cohesion Policy. Moreover, the report presents a roadmap of EU regional and urban datasources.

The Delphi method is applied in the paper "Science-Economy-Technology Concordance Matrix for Development and Implementation of Regional Smart Specializations in the Silesian Voivodeship, Poland" by Smoliński et al. (2015), which explains the developed model that recognises the research and economic components of smart specialisation as well as the connection between the economic components and the technological innovation through the international patent classification. In addition, the method also recognises key enabling technologies. The apparatus of multidimensional statistical analysis was used to yield the findings in the report by Sobczak (2014), which identifies the three smart growth pillars, various indicators, and an individual growth benchmark for regions. In addition, a path for smart growth that was proposed

Using desk research, Dziedzic et al. (2015) reveal the urgency to involve regions in creating an innovation strategy focused on intelligent and sustainable development. Wyrwa (2014) explains how to identify potential areas of smart specialisation in Poland. The authors Mieszkowiski and Kardas (2015) applied innovative foresight techniques to examine the Polish stakeholder involvement in research and innovation policy development. By using regional level analysis, the authors Kuleševičiute and Rybakovas (2015) found that the implementation of smart specialisation in different regions leads to dissimilar outcomes from other priority sectors. Tiits et al. (2015) analyse economic performances and their effectiveness to explain innovation policies and provide recommendations for improvement. Sobczak and Bal-Domaǹska (2015) 
This accepted manuscript is published in the Int. J. Knowledge-Based Development.

Fellnhofer K. (2017): Evidence revisited: Literature on smart specialisation calls for more mixed research designs, International Journal of Knowledge-Based Development, 8(3), 229-248.

applied multivariate statistical analysis to explain how smart growth was created to enact a change in direction in terms of smart specialisation.

\subsection{Mixed Methods}

Out of the 131 discussed papers, only 21 of them used mixed methods, or a combination of quantitative and qualitative research designs. One paper applying mixed methods show the aspects of smart specialisation that require further development (Arancegui et al., 2012). McCann and Ortega-Argilés (2013a, 2013b) inspect the theoretical and empirical changes that shifted stakeholders' attention from innovation-related issues to economic and geographic problems. Valdaliso et al. (2014) show how to operationalise the analyses of continuity and change of science, technology and innovation policies supporting research and innovation strategy policies. Additionally, the types of challenges that the regions in EU will face are discussed. Moreover, Carayannis et al. (2015) explain the dynamics and interactions of intelligent clusters and research and innovation smart specialisation strategies. They also use foresight methods regarding entrepreneurship and innovation ecosystems to focus on open innovation. Another work describes the specificity of the concept of smart specialisation, including its strengths, weaknesses and successful examples (Glińska and Kononiuk, 2013). In the paper "The Expanding of Constructal Law in Economics - A Justification for Crossed Flows of Similar Macro Goods", Dogaru (2016) provides information on identical macro goods that have irreversible bi-univocal aggregated flows among regions in the EU. Moreover, the findings show that the economic flows of the trading products are changing into a new design. Tolias and Emmanouilidis (2014) provide information on current activities regarding the smart specialisation strategies, which suggest that regional innovation policies benefit from strengths and opportunities. They also discuss the methodological problems concerning mapping the sectors and offer guidelines for the design of the regional innovation interventions.

Several papers with mixed methods focused on regions. For instance, the paper titled "Differentiation of English Universities: The Impact of Policy Reforms in Driving a More Diverse Higher Education Landscape" by Purcell et al. (2016) explains that the richness of the Great Britain sector must be portrayed horizontally with stratified excellence by focusing on return on investment. The report titled "A Holistic Approach to Regional Strategies: The Case of the Basque Country" identified and analysed the Basque Country's smart specialisation strategies over the last 30 years (Navarro et al., 2014). A paper by Gadille and Siarheyeva (2014) describes a project that was created in the regional innovation policy framework and provides an improved view of the project implementation regarding the development of a community-based, open innovation network. Suciu et al. (2014) demonstrate how knowledge management influences a company's performance. Another paper provides detailed information on a technological profile of companies that have either synergy or tough competitors in Latvia. The findings in the paper "Identity of Innovative Multifunctional Material Manufacturing Business in Latvia" of Geipele et al. (2015) show that it is important to recognise the factors that stress impact, obtain financial results and determine companies' direction of development. Tatjana et al. (2014) show that the EU's smart specialisation platform is important for regions' economic growth. Sandu (2014) explains the rural development policies implemented in Romania. Paliokaite et al. (2016) discuss the application of Fault Tree Analysis (FTA) methods and the smart specialisation strategies in Lithuania by revealing the methodological assumptions and how the designs differ from proposed guidelines. Another paper describes a methodological approach that differs from the traditional approach (Paliokaite et al., 2015). Its focus was on long-term challenges and critical technologies, which have the advantage of developing synergies and integrated policies. In addition, Tiits and Kalvet (2013) discusses foresight experiences in Estonia so that small catching-up economies do not have to 'piggyback' to success. Markowska and Strahl (2013) report on the Polish assessment of ranking in the European region's background concerning the aggregate measure values in smart 
This accepted manuscript is published in the Int. J. Knowledge-Based Development.

Fellnhofer K. (2017): Evidence revisited: Literature on smart specialisation calls for more mixed research designs, International Journal of Knowledge-Based Development, 8(3), 229-248.

growth pillars. Finally, the work of Bassani et al. (2015) provides guidelines for regional economies regarding technology foresight and listed 24 technologies to use within smart specialiation. Moreover, the evidence provided by Van der Niet et al. (2014) highlights innovative experimental approaches and explains new tools for smart specialisation.

\section{Discussion and conclusion}

The present paper reviews the methods that have been used in previous efforts regarding smart specialisation, highlighting room for improvement to move the research field forward. After reviewing 131 articles concerning smart specialisation from databases such as Scopus, EBSCO and ScienceDirect, it can be concluded that case studies, reviews and interviews represent the dominate qualitative research designs. Only 21 of the 131 contributions use both methodologies. While 26 articles take advantage of quantitative methods, 84 publications focused on qualitative approaches. Considering the need for information on smart specialisation, applying mixed methods becomes more important (Johnson and Onwuegbuzie, 2004), since the findings from these studies tended to be viewed as more rigorous (Doyle et al., 2009).

While reports classified under "qualitative" in this analysis tend to investigate smart specialisation from a policy perspective (e.g. Komninos, 2016; Lerro and Jacobone, 2014), the "quantitative" oriented manuscripts illuminate predominately regional diversification processes and statistics to provide insights for what can be defined as smart specialisation policy (e.g. Gadille and Siarheyeva, 2014; McMillan et al., 2016). This extensive exploration of smart specialisation - from a regional to a European policymaking perspective-highlights the applied methods and draws attention to neglected research designs. Because both qualitative and quantitative methods face advantages and deficiencies, mixed methods are highly recommended for future research. Although other authors would argue that the process-based nature of the smart specialisation concept calls for more qualitative analyses, these methods are considered less rigorous or policy-relevant than quantitative methods. Thus, a mixed approach will take advantage of both methods. It cannot be claimed then that analyses based on mixed methods tend to underestimate the potentials of regions for unconnected diversification, which appears to be an integral element of smart specialisation. Moreover, the works that use both methodologies also provide a better perspective of the smart specialisation itself. Moreover, applying more mixed methods to the study of smart specialisation will also lead to more practical implications, not only for policymakers but also for the business sector. Finally, this review calls for more smart mixed research designs for future specialisation in this research discipline. This review faces some limitations. Because only three different databases were used, it cannot be fully guaranteed that this work included all published documents on smart specialisation. However, the databases used were sufficient to retrieve the information needed to demonstrate which methods and how many research methods are used in smart specialisation research. Additionally, although colleagues may highlight that it is not correct to put case studies, interviews, literature reviews and conceptual discussions all under the same "qualitative methods" umbrella, this decision has been taken in line with prior reviews (e.g., Bouncken et al., 2015). However, throughout the review it has been taken into consideration that some of the reports employ data collection methods, others use data analysis methods and others refer to theories. Therefore, future research should focus on more innovative review approaches such as bibliometric analysis or meta-analysis. This paper provides s a fruitful fundament for such future work. 
This accepted manuscript is published in the Int. J. Knowledge-Based Development.

Fellnhofer K. (2017): Evidence revisited: Literature on smart specialisation calls for more mixed research designs, International Journal of Knowledge-Based Development, 8(3), 229-248. 
This accepted manuscript is published in the Int. J. Knowledge-Based Development.

Fellnhofer K. (2017): Evidence revisited: Literature on smart specialisation calls for more mixed

research designs, International Journal of Knowledge-Based Development, 8(3), 229-248.

\section{References}

Álvarez, M.J., Fernández, R.I. and Romera, R. (2014) 'Is Eco-Innovation a Smart Specialization Strategy for Andalusia? One Approach from the Multivariate Analysis', Revista De Estudios Regionales, Vol., No. 100, pp. 171-195.

Angelidou, M. (2016) 'Four European Smart City Strategies', International Journal of Social Science Studies, Vol. 4, No. 4, pp. 18-30.

Angelidou, M. (2015) 'Smart Cities: A Conjuncture of Four Forces', Cities, Vol. 47, No., pp. 95-106.

Anselmo, A.D. and Cascio, L.L. (2011) 'Towards a New Era for Regional Development: Investing in Leadership', Local Economy, Vol. 26, No. 6-7, pp. 467-472.

Arancegui, M.N., Querejeta, M.J.A. and Montero, E.M. (2012) 'Smart Specialization Strategies: A Territorial Strategy for Regions', Cuadernos De Gestion, Vol. 12, No. SUPPL. PECIALISSU, pp. 27-49.

Bal-Domańska, B. (2013a) 'Does Smart Growth Enhance Economic Cohesion? An Analysis for the Eu Regions of New and Old Accession Countries', Prace Naukowe Uniwersytetu Ekonomicznego we Wrocławiu, Vol., No. 286, pp. 100-110.

Bal-Domańska, B. (2013b) 'Inteligentna Specjalizacja a Spójność Społeczna Regionów Państw Unii Europejskiej-Ocena Relacji Z Wykorzystaniem Modeli Panelowych', Research Papers of the Wroclaw University of Economics/Prace Naukowe Uniwersytetu Ekonomicznego we Wroclawiu, 285.

Baran, A. and Hajduk, S. (2013) 'Intelligent Specialization of Regions as an Instrument to Support Innovation', Actual Problems Of Economics, Vol. 146, No. 8, pp. 202-211.

Bassani, G., Minola, T. and Vismara, S. (2015) Technology Foresight for Regional Economies: A How-to-Do Guide, University Evolution, Entrepreneurial Activity and Regional Competitiveness: Springer International Publishing, Switzerland, 385-392.

Battaglia, A. (2014) 'Creative Industries and Knowledge Economy Development in Rome: The Example of Pietralata District', International Journal of Knowledge-Based Development 8, Vol. 5, No. 3, pp. 238-252.

Bečić, E. and Švarc, J. (2015) 'Smart Specialisation in Croatia: Between the Cluster and Technological Specialisation', Journal of The Knowledge Economy, Vol. 6, No. 2, pp. 270295.

Benner, M. (2014) 'From Smart Specialisation to Smart Experimentation: Building a New Theoretical Framework for Regional Policy of the European Union', Zeitschrift Fur Wirtschaftsgeographie, Vol. 58, No. 1, pp. 33-49.

Borsi, B. and Mikita, J. (2013) 'Centrumok És Perifériák-Régiók Az Európai KutatásFejlesztésben', Közgazdasági Szemle, Vol. 60, No. 4, pp. 431.

Boschma, R. and Boschma, R. (2014) 'Constructing Regional Advantage and Smart Specialisation: Comparison of Two European Policy Concepts', Scienze Regionali, Vol. 13, No. 1, pp. 51-68.

Bouncken, R.B., Gast, J., Kraus, S. and Bogers, M. (2015) 'Coopetition: A Systematic Review, Synthesis, and Future Research Directions', Review of Managerial Science, Vol. 9, No. 3, pp. 577-601.

Brown, F. (2011) 'Optimizing Research Success with Smarter Scientific Informatics', American Laboratory, Vol. 43, No. 6, pp. 46-49.

Camagni, R. and Capello, R. (2013) 'Regional Innovation Patterns and the Eu Regional Policy Reform: Toward Smart Innovation Policies', Growth And Change, Vol. 44, No. 2, pp. 355389.

Camagni, R., Capello, R. and Lenzi, C. (2014) 'A Territorial Taxonomy of Innovative Regions and the European Regional Policy Reform: Smart Innovation Policies', Scienze Regionali, Vol. 13, No. 1, pp. 69-106. 
This accepted manuscript is published in the Int. J. Knowledge-Based Development.

Fellnhofer K. (2017): Evidence revisited: Literature on smart specialisation calls for more mixed

research designs, International Journal of Knowledge-Based Development, 8(3), 229-248.

Capello, R. and Kroll, H. (2016) 'From Theory to Practice in Smart Specialization Strategy: Emerging Limits and Possible Future Trajectories', European Planning Studies, Vol. 24, No. 8, pp. 1-14.

Caragliu, A. and Bo, C.F.D. (2015) Smart Specialization Strategies and Smart Cities: An Evidence-Based Assessment of European Union Policies, The Rise of the City: Spatial Dynamics in the Urban Century: Edward Elgar Publishing Ltd., Cheltenham, UK, Northampton, USA, 55-82.

Carayannis, E.G., Meissner, D. and Edelkina, A. (2015) 'Targeted Innovation Policy and Practice Intelligence (Tip2e): Concepts and Implications for Theory, Policy and Practice', The Journal of Technology Transfer, pp. 1-25.

Carayannis, E.G. and Rakhmatullin, R. (2014) 'The Quadruple/Quintuple Innovation Helixes and Smart Specialisation Strategies for Sustainable and Inclusive Growth in Europe and Beyond', Journal of The Knowledge Economy, Vol. 5, No. 2, pp. 212-239.

Casado, H. (2014) 'How to Boost Innovation from Public Administration', Revista De Obras Publicas, Vol. 161, No. 3550, pp. 31-34.

Casaramona, A., Sapia, A. and Soraci, A. (2015) 'How Toi and the Quadruple and Quintuple Helix Innovation System Can Support the Development of a New Model of International Cooperation', Journal of The Knowledge Economy, Vol. 6, No. 3, pp. 505-521.

CIobotaru, A.-C. (2014) 'The Case for [or Against?] Smart Specialization: Entrepreneurial Process Vs. Weak Interventionism', Review of Economic Studies and Research Virgil Madgearu, Vol. 7, No. 1, pp. 5.

Clar, G. and Sautter, B. (2014) 'Research Driven Clusters at the Heart of (Trans-)Regional Learning and Priority-Setting Processes: The Case of a Smart Specialisation Strategy of a German "Spitzen" Cluster', Journal of The Knowledge Economy, Vol. 5, No. 1, pp. 156-180.

Coffano, M. and Foray, D. (2014) 'The Centrality of Entrepreneurial Discovery in Building and Implementing a Smart Specialisation Strategy', Scienze Regionali, Vol. 13, No. 1, pp. 33-50.

Cooke, P. (2016) 'Four minutes to four years: the advantage of recombinant over specialized innovation-RIS3 versus 'smartspec", European Planning Studies, 1-17.

Del Castillo Hermosa, J., Elorduy, J.P. and Eguía, B.B. (2015) 'Smart Specialization and Entrepreneurial Discovery: Theory and Reality', Revista Portuguesa De Estudos Regionais, Vol. 39, No. 1, pp. 5-22.

Denney, A.S. and Tewksbury, R. (2013) 'How to Write a Literature Review', Journal of Criminal Justice Education, Vol. 24, No. 2, pp. 218-234.

Dogaru, V. (2016) 'The Expanding of Constructal Law in Economics - a Justification for Crossed Flows of Similar Macro Goods', International Journal of Heat and Technology, Vol. 34, No. S1, pp. 59-74.

Doyle, L., Brady, A.-M. and Byrne, G. (2009) 'An Overview of Mixed Methods Research', Journal of Research in Nursing, Vol. 14, No. 2, pp. 175-185.

Dziedzic, S. (2014) 'Nowe Podejście Do Tworzenia Krajowych I Regionalnych Strategii Innowacji-Koncepcja Inteligentnej Specjalizacji (Ris3)', Prace Naukowe Uniwersytetu Ekonomicznego we Wrocławiu, Vol., No. 366, pp. 119-128.

Dziedzic, S., Woźniak, L. and Chrzanowski, M. (2014) 'Crowdsourcing Narzędziem Wzrostu Potencjału Innowacyjnego Przedsiębiorstw Oraz Wzrostu Sprzyjającego Włączeniu Społecznemu', Prace Naukowe Uniwersytetu Ekonomicznego we Wrocławiu, Vol., No. 337, pp. 88-96.

Dziedzic, S., Woźniak, L. and Chrzanowski, M. (2015) 'Inteligentna Specjalizacja Jako Droga Do Zrównoważonego Rozwoju', Prace Naukowe Uniwersytetu Ekonomicznego we Wrocławiu, Vol., No. 377, pp. 167-179.

Dziembała, M. (2015) 'Wspieranie Inteligentnych Specjalizacji Regionów W Unii Europejskiej W Warunkach Globalizac Ji', Research Papers of the Wroclaw University of Economics/Prace Naukowe Uniwersytetu Ekonomicznego we Wroclawiu, 380. 
This accepted manuscript is published in the Int. J. Knowledge-Based Development.

Fellnhofer K. (2017): Evidence revisited: Literature on smart specialisation calls for more mixed

research designs, International Journal of Knowledge-Based Development, 8(3), 229-248.

Dziemianowicz, W. and Peszat, K. (2014) 'Smart Specialisations for Voivodeships - the First Steps toward Improvement?', Miscellanea Geographica, Vol. 18, No. 1, pp. 37-43.

EC (2010) Communication from the Commission Europe 2020 - a Strategy for Smart, Sustainable and Inclusive Growth 3.3.2010 Brussels: European Commission.

Etzkowitz, H. (2003) 'Innovation in Innovation: The Triple Helix of University-IndustryGovernment Relations', Social science information, Vol. 42, No. 3, pp. 293-337.

Etzkowitz, H. and Leydesdorff, L. (2000) 'The Dynamics of Innovation: From National Systems and "Mode 2" to a Triple Helix of University-Industry-Government Relations', Research Policy, Vol. 29, No. 2, pp. 109-123.

Etzkowitz, H. and Leydesdorff, L.A. (1995) Universities and the Global Knowledge Economy: A Triple Helix of University-Industry-Government Relations, London: Pinter.

Fabińska, M. (2013) 'Selected Factors of the Regional Capital Determining Investment Decisions of the Companies Form the Textile and Clothing Sector from Łódź Voivodeship', Prace Naukowe Uniwersytetu Ekonomicznego we Wrocławiu, Vol., No. 307, pp. 109-120.

Ferrari, V., Mion, L. and Molinari, F. (2011) Innovating Ict Innovation: Trentino as a Lab. Paper presented at 5th International Conference on Theory and Practice of Electronic Governance, Icegov 2011, Tallinn.

Feser, E. (2014) 'Planning Local Economic Development in the Emerging World Order', Town Planning Review, Vol. 85, No. 1, pp. 19-38.

Filion, P. (2010) 'Renaissance Thinkers for a Fragmented World', Plan Canada, Vol. 50, No. 3, pp. 40-43.

Fogelberg, H. and Sandén, B.A. (2008) 'Understanding Reflexive Systems of Innovation: An Analysis of Swedish Nanotechnology Discourse and Organization', Technology Analysis \& Strategic Management, Vol. 20, No. 1, pp. 65-81.

Foray, D. (2014) 'From Smart Specialisation to Smart Specialisation Policy', European Journal of Innovation Management, Vol. 17, No. 4, pp. 492-507.

Foray, D. (2015) Smart Specialisation: Opportunities and Challenges for Regional Innovation Policy, Abingdon: Routledge.

Foray, D., DAVID, P.A. and HALL, B.H. (2011) Smart Specialisation from Academic Idea to Political Instrument, the Surprising Career of a Concept and the Difficulties Involved in Its Implementation: EPFL, Lausanne, Switzerland.

Foray, D., Goddard, J., Goenaga Beldarrain, X., Landabaso, M., McCann, P., Morgan, K., Nauwelaers, C. and Ortega-Argilés, R. (2012) Guide to Research and Innovation Strategies for Smart Specialisation (Ris 3), Smart Specialisation Platform, Regional Policy. available at http://s3platform.jrc.ec.europa.eu/s3pguide: European Commission.

Gadille, M. and Siarheyeva, A. (2014) 'Open Innovation Network and Implications for Specialisation of a Small Urban Area', International Journal Of Knowledge-Based Development, Vol. 5, No. 2, pp. 152-172.

Garrett-Jones, S., Turpin, T., Burns, P. and Diment, K. (2005) 'Common Purpose and Divided Loyalties: The Risks and Rewards of Cross-Sector Collaboration for Academic and Government Researchers', $R \& D$ Management, Vol. 35, No. 5, pp. 535-544.

Geipele, I., Staube, T., Ciemleja, G., Zeltins, N. and Ekmanis, Y. (2015) 'Identity of Innovative Multifunctional Material Manufacturing Business in Latvia', Latvian Journal of Physics And Technical Sciences, Vol. 52, No. 4, pp. 3-17.

Georghiou, L., Uyarra, E., Scerri, R.S., Castillo, N. and Harper, J.C. (2014) 'Adapting Smart Specialisation to a Micro-Economy - the Case of Malta', European Journal of Innovation Management, Vol. 17, No. 4, pp. 428-447.

Gheorghiu, R., Andreescu, L. and Curaj, A. (2016) 'A Foresight Toolkit for Smart Specialization and Entrepreneurial Discovery', Futures, Vol. 80, pp. 33-44. 
This accepted manuscript is published in the Int. J. Knowledge-Based Development.

Fellnhofer K. (2017): Evidence revisited: Literature on smart specialisation calls for more mixed

research designs, International Journal of Knowledge-Based Development, 8(3), 229-248.

Glińska, E. and Kononiuk, A. (2013) 'The Concept of Regional Strategy of Smart Specialization', Prace Naukowe Uniwersytetu Ekonomicznego we Wrocławiu, Vol., No. 286, pp. 27-34.

Golec, A. and Lipińska, K.N. (2015) 'Pomeranian Creativity Port. Examples of ProEnterepreneurial Activities of Pomeranian Voivodeship', Studia BAS, Vol. 1, No. 1, pp. 159174.

Gonzalez, A.V., Mack, E.A. and Flores, M. (2016) 'Industrial Complexes in Mexico: Implications for Regional Industrial Policy Based on Related Variety and Smart Specialization', Regional Studies, pp. 1-11.

Grant, K.A. and Chuang, S. (2012) 'An Aggregating Approach to Ranking Cities for Knowledge-Based Development', International Journal of Knowledge-Based Development, Vol. 3, No. 1, pp. 17-34.

Gridneva, L. and Noennig, J.R. (2014) 'The Creative City Matrix: A Framework for Urban Knowledge Ecosystems', International Journal of Knowledge-Based Development 8, Vol. 5, No. 3, pp. 289-310.

Grillitsch, M. (2016) 'Institutions, Smart Specialisation Dynamics and Policy', Environment And Planning C-Government And Policy, Vol. 34, No. 1, pp. 22-37.

Gulc, A. (2015a) 'Analysis of Methodological Approach to Identify Smart Specialization on the Example of Polish Regions', Procedia-Social and Behavioral Sciences, Vol. 213, pp. 817823.

Gulc, A. (2015b) 'Role of Smart Specialisation in Financing the Development of Regions in Perspective 2020', Business, Management and Education, Vol., No. 1, pp. 95-111.

Han, K., Lee, E.G., Je, H. and Mun, Y.Y. (2016) Introducing Experiential Knowledge Platform: A Smart Decision Supporter for Field Experts. Paper presented at 2016 International Conference on Big Data and Smart Computing (BigComp).

Hildreth, P. and Bailey, D. (2014) 'Place-Based Economic Development Strategy in England: Filling the Missing Space', Local Economy, Vol. 29, No. 4-5, pp. 363-377.

Howells, J., Ramlogan, R. and Cheng, S.-L. (2012) 'Innovation and University Collaboration: Paradox and Complexity within the Knowledge Economy', Cambridge Journal of Economics, Vol. 36, No. 3, pp. 703-721.

Iacobucci, D. (2014) 'Designing and Implementing a Smart Specialisation Strategy at Regional Level: Some Open Questions', Scienze Regionali, Vol. 13, No. 1, pp. 107-126.

Iacobucci, D. and Guzzini, E. (2016) 'Relatedness and Connectivity in Technological Domains: Missing Links in S3 Design and Implementation', European Planning Studies, Vol. 24, No. 8, pp. 1511-1526.

Ioana, M.I., Anda, M.I., Ioan, P. and Bianca, R.A. (2015) 'The Importance of Community Involvement in Research and Innovation between 2014-2020', Procedia-Social and Behavioral Sciences, Vol. 182, No., pp. 619-622.

Jishnu, V., Gilhotra, R. M., and Mishra, D. N. (2011) 'Pharmacy education in India: Strategies for a better future', Journal of Young Pharmacists, Vol. 3, No. 4, pp. 334-342.

Johnson, R.B. and Onwuegbuzie, A.J. (2004) 'Mixed Methods Research: A Research Paradigm Whose Time Has Come', Educational Researcher, Vol. 33, No. 7, pp. 14-26.

Karo, E. and Kattel, R. (2015) 'Economic Development and Evolving State Capacities in Central and Eastern Europe: Can "Smart Specialization” Make a Difference?', Journal of Economic Policy Reform, Vol. 18, No. 2, pp. 172-187.

Kim, H., You, T., Ahn, S.-J. and Jung, W.-S. (2016) 'Embracing Networks of National Policy Research in Future Foresight', International Journal of Knowledge-Based Development, Vol. 7, No. 2, pp. 107-124.

Knašas, A.B. (2014) 'Mokslinè-Techninè Pažanga Lietuvoje Paskelbtų Patentinių Paraiškų Požiūriu', Regional Formation and Development Studies, Vol. 12, No. 1, pp. 143-156. 
This accepted manuscript is published in the Int. J. Knowledge-Based Development.

Fellnhofer K. (2017): Evidence revisited: Literature on smart specialisation calls for more mixed

research designs, International Journal of Knowledge-Based Development, 8(3), 229-248.

Komninos, N. (2016) 'Smart Environments and Smart Growth: Connecting Innovation Strategies and Digital Growth Strategies', International Journal of Knowledge-Based Development, Vol. 7, No. 3, pp. 240-263.

Komninos, N., Musyck, B. and Reid, A.I. (2014) 'Smart Specialisation Strategies in South Europe During Crisis', European Journal Of Innovation Management, Vol. 17, No. 4, pp. 448-471.

Korkosz-Gębska, J. (2015) 'Znaczenie Innowacji Ekologicznych W Budowaniu Przewagi Konkurencyjnej Regionu Na Przykładzie Województwa Podlaskiego', Zeszyty Naukowe. Organizacja i Zarzadzanie/Politechnika Ślaska, Vol., No. 83, pp. 283-292.

Koszarek, M. (2014) 'Supporting the Development of Clusters in Poland-Dilemmas Faced by Public Policy', Research Papers of the Wroclaw University of Economics/Prace Naukowe Uniwersytetu Ekonomicznego we Wroclawiu, 365.

Kowch, E.G. (2012) Towards Leading Diverse, Smarter and More Adaptable Organizations That Learn, Technology as a Tool for Diversity Leadership: Implementation and Future Implications: IGI Global, Hershey, PA, USA, 11-34.

Kroll, H. (2015) 'Efforts to Implement Smart Specialization in Practice-Leading Unlike Horses to the Water', European Planning Studies, Vol. 23, No. 10, pp. 2079-2098.

Kroll, H., Böke, I., Schiller, D. and Stahlecker, T. (2016) 'Bringing Owls to Athens? The Transformative Potential of Ris3 for Innovation Policy in Germany's Federal States', European Planning Studies, Vol. 24, No. 8, pp. 1459-1477.

Kropelnytska, S. and Vusyatytska, M. (2015) 'Institutional and Financial Support for Regional Innovation Development Based on Cluster Approach', Economic Annals-Xxi, Vol. 3-4, No. 2, pp. 37-40.

Kuleševičiute, A.O. and Rybakovas, E. (2015) 'Industrial Preconditions for Smart Specialization of Lithuania Regions', Public Policy And Administration, Vol. 14, No. 1, pp. 129-144.

Kyriakou, D. (2014) Economic Impact of Smart Specialization and Research in Advanced Adaptive Systems in a Monetary Union, The Robotics Divide: A New Frontier in the 21st Century?: Springer-Verlag London Ltd, London, 41-58.

Landabaso, M. (2014) 'Guest Editorial on Research and Innovation Strategies for Smart Specialisation in Europe: Theory and Practice of New Innovation Policy Approaches', European Journal Of Innovation Management, Vol. 17, No. 4, pp. 378-389.

Lerro, A. and Jacobone, F. (2014) 'Smart Growth, Smart Specialisations Strategies and Impact of the Technological Districts: The Moderating Effect of Business, Geographical and Institutional Factors', International Journal Of Knowledge-Based Development, Vol. 5, No. 3, pp. 221-237.

Maeng, D.M. and Nedovic-Budic, Z. (2010) 'Relationship between Ict and Urban Form in Knowledge-Based Development: Empirical Analysis of Washington, Dc Metro Region', International Journal of Knowledge-Based Development, Vol. 1, No. 1-2, pp. 97-117.

Malik, K. (2014) 'Smart Specialisation and Key Enabling Technologies in the New Regional Development Policy', Research Papers of the Wroclaw University of Economics/Prace Naukowe Uniwersytetu Ekonomicznego we Wroclawiu, 334.

Markowska, M. (2014) 'Ocena Zależności Między Rozwojem Inteligentnym a Odpornością Na Kryzys Ekonomiczny W Wymiarze Regionalnym-Przegląd Badań [Assessment of Dependence between Smart Growth and Resilience to Economic Crisis in Regional Dimension-Research Review,[In:] Gospodarka Regionalna W Teorii I Praktyce [Regional Economy in Theory and Practice], D. Strahl, A. Raszkowski and D. Głuszczuk', Research Studies of Wrocław University of Economics, Wrocław, Vol., No. 333, pp. 22-32.

Markowska, M. and Jefmański, B. (2012) 'Fuzzy Classification of European Regions in the Evaluation of Smart Growth', Przeglad Statystyczny, Vol. 59, No. 1, pp. 74-93. 
This accepted manuscript is published in the Int. J. Knowledge-Based Development.

Fellnhofer K. (2017): Evidence revisited: Literature on smart specialisation calls for more mixed

research designs, International Journal of Knowledge-Based Development, 8(3), 229-248.

Markowska, M. and Strahl, D. (2013) 'Polish Regions against the Background of European Regional Space with Regard to Smart Growth-Aggregate Perspective', Prace Naukowe Uniwersytetu Ekonomicznego we Wrocławiu, Vol., No. 286, pp. 89-99.

Martinus, K. (2012) 'City Infrastructure Supporting Innovation', International Journal of Knowledge-Based Development, Vol. 3, No. 2, pp. 126-156.

McCann, P. (2015) The Regional and Urban Policy of the European Union: Cohesion, ResultsOrientation and Smart Specialisation: Edward Elgar Publishing Ltd, Cheltenham, UK, Northampton, USA.

McCann, P. and Ortega-Argiles, R. (2015) 'Smart Specialization, Regional Growth and Applications to European Union Cohesion Policy', Regional Studies, Vol. 49, No. 8, pp. 1291-1302.

McCann, P. and Ortega-Argiles, R. (2013b) 'Transforming European Regional Policy: A Results-Driven Agenda and Smart Specialization', Oxford Review of Economic Policy, Vol. 29, No. 2, pp. 405-431.

McCann, P. and Ortega-Argilés, R. (2016a) 'The Early Experience of Smart Specialization Implementation in Eu Cohesion Policy', European Planning Studies, Vol. 24, No. 8, pp. 1407-1427.

McCann, P. and Ortega-Argilés, R. (2013a) 'Modern Regional Innovation Policy', Cambridge Journal Of Regions, Economy And Society, Vol. 6, No. 2, pp. 187-216.

McCann, P. and Ortega-Argilés, R. (2014a) 'The Role of the Smart Specialisation Agenda in a Reformed Eu Cohesion Policy', Scienze Regionali, Vol. 13, No. 1, pp. 15-32.

McCann, P. and Ortega-Argilés, R. (2014b) 'Smart Specialisation in European Regions: Issues of Strategy, Institutions and Implementation', European Journal of Innovation Management, Vol. 17, No. 4, pp. 409-427.

McCann, P. and Ortega-Argilés, R. (2016b) 'Smart Specialisation, Entrepreneurship and Smes: Issues and Challenges for a Results-Oriented Eu Regional Policy', Small Business Economics, Vol. 46, No. 4, pp. 537-552.

McCann, P. and Varga, A. (2015) 'The Reforms to the Regional and Urban Policy of the European Union: Eu Cohesion Policy', Regional Studies, Vol. 49, No. 8, pp. 1255-1257.

McMillan, G.S., Bezzina, F. and Casey, D.L. (2016) 'Smart Specialisation in Malta: A Bibliometric Look at Aquaculture', International Journal of Technology Intelligence And Planning, Vol. 11, No. 1, pp. 51-61.

Mempel-Śnieżyk, A. (2013) 'Smart Specialisation and Clusters in Economic Growth', Prace Naukowe Uniwersytetu Ekonomicznego we Wrocławiu, 324, pp. 92-103.

Mieszkowski, K. and Kardas, M. (2015) 'Facilitating an Entrepreneurial Discovery Process for Smart Specialisation. The Case of Poland', Journal of The Knowledge Economy, Vol. 6, No. 2, pp. 357-384.

Miłek, D. and Kapusta, K. (2015) 'Competitiveness of the Regions in the Context of Smart Specialization (on the Example of Swiętokrzyskie)', Research Papers of the Wroclaw University of Economics/Prace Naukowe Uniwersytetu Ekonomicznego we Wroclawiu, Vol., No. 401, pp.

Monsson, C.K. (2014) 'Development without a Metropolis: Inspiration for Non-Metropolitan Support Practices from Denmark', Local Economy, Vol. 29, No. 4-5, pp. 295-308.

Morgan, K. (2016). 'Collective entrepreneurship: the Basque model of innovation', European Planning Studies, pp. 1-17.

Morgan, K. (2015) 'Smart Specialisation: Opportunities and Challenges for Regional Innovation Policy', Regional Studies, Vol. 49, No. 3, pp. 480-482.

Muscio, A., Reid, A. and Rivera Leon, L. (2015) 'An Empirical Test of the Regional Innovation Paradox: Can Smart Specialisation Overcome the Paradox in Central and Eastern Europe?', Journal Of Economic Policy Reform, Vol. 18, No. 2, pp. 153-171. 
This accepted manuscript is published in the Int. J. Knowledge-Based Development.

Fellnhofer K. (2017): Evidence revisited: Literature on smart specialisation calls for more mixed

research designs, International Journal of Knowledge-Based Development, 8(3), 229-248.

Naldi, L., Nilsson, P., Westlund, H. and Wixe, S. (2015) 'What Is Smart Rural Development?', Journal Of Rural Studies, Vol. 40, No., pp. 90-101.

Nastase, C., Chasovschi, C., Popescu, M. and Boghean, C. (2012) Industrial Change and Eu Programmes in Creating a Favourable Environment, Norristown: Int Business Information Management Assoc-Ibima.

Navarro, M., Valdaliso, J.M., Aranguren, M.J. and Magro, E. (2014) 'A Holistic Approach to Regional Strategies: The Case of the Basque Country', Science And Public Policy, Vol. 41, No. 4, pp. 532-547.

Nordberg, K. (2015) 'Enabling Regional Growth in Peripheral Non-University Regions - the Impact of a Quadruple Helix Intermediate Organisation', Journal Of The Knowledge Economy, Vol. 6, No. 2, pp. 334-356.

O'Leary, E. (2015) Irish Economic Development: High-Performing Eu State or Serial underAchiever?: Taylor and Francis Inc, Abington, Oxon, UK, New York, NY, USA.

Olaniyi, E.O. and Reidolf, M. (2015) 'Organisational Innovation Strate Gies in the Context of Smart Specialization', Journal Of Security And Sustainability Issues, Vol. 5, No. 2, pp. 213 227.

Paliokaite, A., Martinaitis, Z. and Reimeris, R. (2015) 'Foresight Methods for Smart Specialisation Strategy Development in Lithuania', Technological Forecasting And Social Change, Vol. 101, No. Dec, pp. 185-199.

Paliokaite, A., Martinaitis, Ž. and Sarpong, D. (2016) 'Implementing Smart Specialisation Roadmaps in Lithuania: Lost in Translation?', Technological Forecasting And Social Change, Vol. 110, No., pp. 143-152.

Pauna, C.B. (2015) Cross-Sectoral Cooperation Vs. Cluster Development at European Level, In Luminita, C., Constantin, C. and Valeriu, I.F. (eds.), 2nd International Conference Economic Scientific Research - Theoretical, Empirical and Practical Approaches, Espera 2014. Amsterdam: Elsevier Science Bv, 175-183.

Peck, F., Connolly, S., Durnin, J. and Jackson, K. (2013) 'Prospects for 'Place-Based' Industrial Policy in England: The Role of Local Enterprise Partnerships', Local Economy, Vol. 28, No. 7-8, pp. 828-841.

Perło, D. (2015) 'Clusters and Smart Specializations', Research Papers of the Wroclaw University of Economics/Prace Naukowe Uniwersytetu Ekonomicznego we Wroclawiu, Vol., No. 394, pp.

Perry, P., Wise, W., O'Neill, D. and Jensen, M. (2011) Leveraging a Technical Domain Taxonomy to Enhance Collaboration, Knowledge Sharing and Operational Support. Paper presented at Spe Digital Energy Conference And Exhibition 2011, The Woodlands, TX.

Petraite, M. and Ceicyte, J. (2014) Conceptual Model for Responsible Innovation Management in Business Organizations, In Gimzauskiene, E. (ed.), 19th International Scientific Conference Economics and Management 2014. Amsterdam: Elsevier Science Bv, 121-124.

Presenza, A., Micera, R., Splendiani, S. and Del Chiappa, G. (2014) 'Stakeholder EInvolvement and Participatory Tourism Planning: Analysis of an Italian Case Study', International Journal of Knowledge-Based Development 8, Vol. 5, No. 3, pp. 311-328.

Purcell, W.M., Beer, J. and Southern, R. (2016) 'Differentiation of English Universities: The Impact of Policy Reforms in Driving a More Diverse Higher Education Landscape', Perspectives: Policy And Practice In Higher Education, Vol. 20, No. 1, pp. 24-33.

Reimeris, R. (2016) 'New Rules, Same Game: The Case of Lithuanian Smart Specialization', European Planning Studies, Vol. 24, No. 8, pp. 1561-1583.

Romano, A., Passiante, G., Del Vecchio, P. and Secundo, G. (2014) 'The Innovation Ecosystem as Booster for the Innovative Entrepreneurship in the Smart Specialisation Strategy', International Journal of Knowledge-Based Development, Vol. 5, No. 3, pp. 271-288.

Rosiello, A., Mastroeni, M., Castle, D. and Phillips, P.W.B. (2015) 'Clusters, Technological Districts and Smart Specialisation: An Empirical Analysis of Policy Implementation 
This accepted manuscript is published in the Int. J. Knowledge-Based Development.

Fellnhofer K. (2017): Evidence revisited: Literature on smart specialisation calls for more mixed

research designs, International Journal of Knowledge-Based Development, 8(3), 229-248.

Challenges', International Journal of Entrepreneurship and Innovation Management, Vol. 19, No. 5-6, pp. 304-326.

Rucinski, A., Miller, M., and Girek, M. (2013) 'Prescription for Poland: Disruptive innovative e-Health ecosystem for regenerative medicine in Poland', In Intelligent Data Acquisition and Advanced Computing Systems (IDAACS), IEEE 7th International Conference on, Vol. 2, pp. 551-554.

Rusu, M. (2013) 'Smart Specialization a Possible Solution to the New Global Challenges', Procedia Economics and Finance, Vol. 6, No., pp. 128-136.

Sandu, A.M. (2014) 'Coordinates of the New Eu Rural Development Policy', Quality - Access To Success, Vol. 15, No. SUPPL.1, pp. 463-465.

Sandu, S. (2012) Smart Specialization Concept and the Status of Its Implementation in Romania, In Stefan, D. and Comes, C.A. (eds.), International Conference Emerging Markets Queries in Finance and Business. Amsterdam: Elsevier Science Bv, pp. 236-242.

Santini, C., Marinelli, E., Boden, M., Cavicchi, A. and Haegeman, K. (2016) 'Reducing the Distance between Thinkers and Doers in the Entrepreneurial Discovery Process: An Exploratory Study', Journal of Business Research, Vol. 69, No. 5, pp. 1840-1844.

Santos, D. and Caseiro, N. (2015) The Challenges of Smart Specialization Strategies and the Role of Entrepreneurial Universities: A New Competitive Paradigm, Handbook of Research on Global Competitive Advantage through Innovation and Entrepreneurship: IGI Global, Hershey, PA, USA, 537-551.

Scutaru, L. (2015) 'Potential of Smart Specialization of Clusters in Romania', The USV Annals of Economics and Public Administration, Vol. 15, No. 3, pp. 62-70.

Secundo, G., Del Vecchio, P. and Passiante, G. (2015) 'Creating Innovative Entrepreneurial Mindsets as a Lever for Knowledge-Based Regional Development', International Journal of Knowledge-Based Development, Vol. 6, No. 4, pp. 276-298.

Shinn, T. (2002) 'The Triple Helix and New Production of Knowledge Prepackaged Thinking on Science and Technology', Social Studies of Science, Vol. 32, No. 4, pp. 599-614.

Simonen, J., Svento, R. and Juutinen, A. (2015) 'Specialization and Diversity as Drivers of Economic Growth: Evidence from High-Tech Industries', Papers in Regional Science, Vol. 94, No. 2, pp. 229-247.

Smoliński, A., Bondaruk, J., Pichlak, M., Trząski, L. and Uszok, E. (2015) 'Science-EconomyTechnology Concordance Matrix for Development and Implementation of Regional Smart Specializations in the Silesian Voivodeship, Poland', Scientific World Journal, Vol. 2015.

Sobczak, E. (2014) 'Harmonijność Inteligentnego Rozwoju Regionów Unii Europejskiej', Prace Naukowe Uniwersytetu Ekonomicznego we Wroctawiu, Vol., No. 328, pp. 21-29.

Sobczak, E. and Bal-Domaǹska, B. (2015) Smart Growth Path as the Basis for the European Union Countries Typology. Paper presented at 1st European Conference On Data Analysis, Ecda 2013.

Suciu, M.C., Florea, C.A. and Teodorescu, I. (2014) Integration of Knowledge Management into Business Process, In Vivas, C. and Sequeira, P. (eds.), Proceedings of the 15th European Conference on Knowledge Management. Nr Reading: Acad Conferences Ltd, 932-938.

Tatjana, S., Guna, C. and Ineta, G. (2014) The Origins of Nanotechnology in Latvia.In Song, H.M., Son, H.K. and Hu, J.W. editors), 2014 International Conference On Advanced Materials, Structures And Mechanical Engineering, Icamsme 2014: Trans Tech Publications Ltd.

Tiits, M. and Kalvet, T. (2013) 'Intelligent Piggybacking: A Foresight Policy Tool for Small Catching-up Economies', International Journal of Foresight And Innovation Policy, Vol. 9, No. 2-4, pp. 253-268.

Tiits, M., Kalvet, T. and Mürk, I. (2015) 'Smart Specialisation in Cohesion Economies', Journal of The Knowledge Economy, Vol. 6, No. 2, pp. 296-319. 
This accepted manuscript is published in the Int. J. Knowledge-Based Development.

Fellnhofer K. (2017): Evidence revisited: Literature on smart specialisation calls for more mixed

research designs, International Journal of Knowledge-Based Development, 8(3), 229-248.

Todeva, E. (2015) 'Market-Driven Clusters as Prerequisites and Consequences of Smart Specialisation', Journal Of The Knowledge Economy, Vol. 6, No. 2, pp. 250-269.

Tolias, Y.A. and Emmanouilidis, C. (2014) Cross-Mapping of Regional Research and Production Landscapes: Methodological Issues and Implications for Elaborating Regional Innovation Strategies. Paper presented at 2014 International Conference on Engineering, Technology and Innovation, Ice 2014, Bergamo.

Tomaszuk, A. (2015) 'Rozwój Inteligentnych Specjalizacji W Województwie Podlaskim', Zeszyty Naukowe. Organizacja i Zarządzanie/Politechnika Śląska, Vol., No. 83, pp. 681690.

Tsan, W.N., Chang, C., Lin, B.C., Han, W.Y. and Chu, N.S. (2012) 'The Industrial Specialization and Economic Contribution of the Smartphone Supply Chain: The Case of Apple and Htc', International Journal Of Automation And Smart Technology, Vol. 2, No. 3, pp. 177-188.

Valdaliso, J.M., Magro, E., Navarro, M., Aranguren, M.J. and Wilson, J.R. (2014) 'Path Dependence in Policies Supporting Smart Specialisation Strategies: Insights from the Basque Case', European Journal Of Innovation Management, Vol. 17, No. 4, pp. 390-408.

Van der Niet, T., Peakall, R. and Johnson, S.D. (2014) 'Pollinator-Driven Ecological Speciation in Plants: New Evidence and Future Perspectives', Annals of Botany, Vol. 113, No. 2, pp. 199-211.

van Oort, F., de Geus, S. and Dogaru, T. (2015) 'Related Variety and Regional Economic Growth in a Cross-Section of European Urban Regions', European Planning Studies, Vol. 23, No. 6, pp. 1110-1127.

Vanthillo, T. and Verhetsel, A. (2012) 'Paradigm Change in Regional Policy: Towards Smart Specialisation? Lessons from Flanders (Belgium)', Belgeo, No. 1-2.

Wilson, B., Hogan, A., Cuthill, M., Baker, D., Buys, L. and Burton, L. (2015) 'Someone Else's Boom but Always Our Bust: Australia as a Derivative Economy, Implications for Regions', Regional Science Policy and Practice, Vol. 7, No. 2, pp. 75-87.

Wyrwa, J. (2014) 'Smart Specialisation-a Novel Approach Towards Region Development in Poland', Acta Scientiarum Polonorum. Oeconomia, Vol. 13, No. 3.

Yigitcanlar, T. (2014) 'Innovating Urban Policymaking and Planning Mechanisms to Deliver Knowledge-Based Agendas: A Methodological Approach', International Journal of Knowledge-Based Development 8, Vol. 5, No. 3, pp. 253-270.

Zaman, G. and Georgescu, G. (2015) 'Regional Economic Resilience in Romania. The Duration and Speed of Gdp Decline Recovery at Country Level', The Annals of the University of Oradea, No. 2, pp. 92. 